\title{
Methanogenesis and clay minerals diagenesis during the formation of dolomite nodules from the Tortonian marls of southern Spain
}

\author{
Pierre Catherine ${ }^{1,{ }^{*}}$, Rouchy Jean-Marie ${ }^{2}$, Blanc Valleron Marie-Madeleine ${ }^{2}$, Etoubleau Joël ${ }^{3}$, \\ Fouquet Yves ${ }^{3}$
}

${ }^{1}$ Sorbonne Universités- UPMC- LOCEAN, 4 Place Jussieu, 75252 Paris Cedex 05, France

${ }^{2}$ Sorbonne Universités - MNHN, CNRS, UPMC-Paris 6, CR2P, 57 rue Cuvier, CP 48, F-75005, Paris, France

${ }^{3}$ Ifremer, Géosciences marines, 29280 Plouzané, France

* Corresponding author : Tel.: +33144275162. ; email address : catherine.pierre@locean-ipsl.upmc.fr

\begin{abstract}
:
Dolomite nodules are widespread within the Tortonian marls of Fortuna and Lorca basins in southern Spain. They occur as large bodies of various forms (round, ovoid, tabular) that are parallel or secant relative to the stratification. They are massive and present sometimes internal conduits that are considered as drains used for the migration of fluids. This study brings new results on the mineralogy and elemental and isotopic geochemistry of these dolomite nodules to better describe the processes that were occurring during their formation. The diagenetic reactions that have driven authigenic dolomite precipitation within the sediments involved on the one hand methanogenesis that produced 13C-poor $\mathrm{CH} 4$ and $13 \mathrm{C}$-rich $\mathrm{CO} 2$, on the other hand carbonate and silicate weathering by the CO2-rich solutions, that released respectively alkalinity and cations in pore solutions. Moreover, the distribution of the major elements ( $\mathrm{Si}, \mathrm{Al}, \mathrm{K}, \mathrm{Na}, \mathrm{Ca}, \mathrm{Mg}, \mathrm{Fe}$ ) in the marls and dolomite nodules indicates that these elements were redistributed within the sedimentary formation during the diagenetic reactions without external inputs by the circulating fluids. These observations thus confirm the link between authigenic dolomite formation and clay minerals diagenesis in sediments where methanogenesis was active.
\end{abstract}

\section{Highlights}

- The ${ }^{13} \mathrm{C}$-rich dolomite nodules of SE Spain are related to methanogenesis. Methanogenesis delivered ${ }^{13} \mathrm{C}$-poor $\mathrm{CH}_{4}$ and ${ }^{13} \mathrm{C}$-rich $\mathrm{CO}_{2}$ in pore solutions. Carbonate and clays weathering by $\mathrm{CO}_{2}$ of fluids provided cations and bicarbonate.

Keywords: authigenic dolomite nodules, elemental geochemistry, oxygen and carbon isotopes, methanogenesis, clay minerals diagenesis 


\section{1- Introduction}

Authigenic carbonate nodules have been described both in exposed sedimentary successions and in marine and lacustrine sediments (e.g. Aiello, 2005, Campbell et al., 2002, Capozzi et al., 2012, Curtis and Coleman, 1986, Irwin et al., 1977, Kelts and McKenzie, 1982, Pierre and Rouchy, 2004). Numerous examples of methane derived authigenic carbonates, either with very low $\delta^{13} \mathrm{C}$ values or to very high $\delta^{13} \mathrm{C}$ values associated to marine cold seeps or to organic/hydrocarbon-rich sediments, have been studied in the past two decades, providing an integrated description of the biogeochemical processes that are responsible for the precipitation of carbonates in these specific environments (e.g. Aloisi et al., 2000, Bayon et al., 2007, Bohrmann et al., 1998, Crémière et al., 2012, Peckmann et al., 2001, Pierre et al., 2012, Roberts et al., 2010). The authigenic carbonate nodules occur generally within marly to silty/sandy deposits where the carbonate cement growth is sometimes obviously linked to the presence of preferential drains (conduit, fault, sedimentary discontinuity) that are thought to have favoured the circulation of fluids. However, in many cases these carbonate nodules appear to be distributed randomly without any evidence of structural or sedimentary control for their occurrence.

Authigenic carbonate nodules display also considerable variations in size and morphology, from $\mathrm{mm}$ to pluri-meter bodies with various shapes (round, elongated, contorted) that may be distributed in layers or be secant to the stratification. The carbonate mineralogy comprises various phases consisting of calcium carbonate (aragonite, magnesian calcite), dolomite and siderite that may be present as complex mixtures in the same nodule (Pierre et al., 2014).

The formation of authigenic carbonate in an unconsolidated sediment requires inputs of both bicarbonate ions and cations from pore solutions with steady conditions during enough time to maintain carbonate over-saturation.

The link between authigenic carbonates and hydrocarbon-rich fluids is evidenced by the very negative $\delta^{13} \mathrm{C}$ values indicating that microbial oxidation of hydrocarbons (mostly 
methane) is the source of dissolved inorganic carbon (DIC) in the pore solutions (Claypool and Threlkeld, 1983). The anaerobic oxidation of methane (AOM) coupled with bacterial sulphate reduction $\left(\mathrm{SO}_{4}{ }^{2-}+\mathrm{CH}_{4} \rightarrow \mathrm{HCO}_{3}{ }^{-}+\mathrm{HS}^{-}+\mathrm{H}_{2} \mathrm{O}\right)$ represents the most important reaction in sediments for producing both DIC and hydrogen sulphide in pore solutions (Boetius et al., 2000, Hinrichs et al., 2000, Orphan et al. 2001).

Another source of DIC may be provided by carbonate or silicate chemical weathering by $\mathrm{CO}_{2}$-rich solutions (i.e. hydrolysis) also called " $\mathrm{CO}_{2}$ buffering" by Claypool and Threlkeld, (1983), as in anoxic diagenetic environments where methanogenesis is active (Claypool and Threlkeld, 1983, Wallmann et al., 2008). The term silicate weathering was firstly used by Wallmann et al. in 2008 and corresponds to the diagenetic process that changes the chemical and mineralogical composition of marine sediments and buffers the $\mathrm{CO}_{2}$-rich pore fluids. During the methanogenesis reaction resulting from organic matter fermentation (2 $\mathrm{CH}_{2} \mathrm{O} \rightarrow \mathrm{CO}_{2}+\mathrm{CH}_{4}$ ) the large ${ }^{13} \mathrm{C}$ fractionation produces ${ }^{13} \mathrm{C}$-depleted $\mathrm{CH}_{4}$ (down to $110 \%$ ) and ${ }^{13} \mathrm{C}$-rich $\mathrm{CO}_{2}$ (up to $+15 \%$ ) (Rosenfeld and Silverman, 1959; Claypool and Kaplan, 1974). The silicate weathering by $\mathrm{CO}_{2}$ produced by methanogenesis appears as a major diagenetic process because it produces large amounts of DIC in the pore solutions (characterized by very high $\delta^{13} \mathrm{C}$ values) and it releases cations (i.e. $\mathrm{Ca}^{2+}, \mathrm{Mg}^{2+}, \mathrm{Fe}^{2+}$ ) that are thus available for authigenic carbonate precipitation.

Overall, these processes (AOM, methanogenesis, silicate weathering) are the major sources of DIC in pore solutions of organic-rich sediments as in the Bering Sea where DIC reaches up to $74 \mathrm{mM}$ i.e. 37 times the DIC concentration of seawater (Wehrmann et al., 2011).

This study compares mineralogy, elemental geochemistry and oxygen and carbon stable isotopes of carbonate, in selected samples of authigenic carbonate nodules and of unconsolidated surrounding sediments, from the Tortonian marls of southern Spain, to confirm or not the link between silicate weathering and the formation of authigenic carbonate in relation with methanogenesis.

\section{2- Geological context and sedimentary sampling}

The Lorca and Fortuna Neogene basins are part of a series of intramontane basins located in the internal zone or at the transition between the internal and external zones of the Betic Cordillera in SE Spain (Fig 1). The sedimentation that started in the earliest Tortonian comprises a thick succession of Tortonian marls deposited in the subsiding depocentre which 
grades upward into a regressive succession made of diatomite-bearing deposits and evaporites. The Tortonian marls represent an homogeneous unit up to $1200 \mathrm{~m}$ in thickness in the central part of the Lorca Basin, which contains discontinuous levels of indurated nodules of diagenetic dolomite. The dolomite nodules from Tortonian marls of the Lorca Basin and other series of SE Spain and Morocco were described in previous studies where their formation was linked to alternating episodes of gas hydrate formation/dissociation with massive methane release during the successive sea level drops of the Messinian salinity crisis (Pierre et al., 2002, Pierre and Rouchy, 2004). In the Fortuna Basin, similar dolomite nodules are also present as in the outcropping 30 m-thick section of « La rambla del Font » (Fig. 2). Due to the vertical and lateral discontinuity of the outcrops in the two basins of Lorca and Fortuna that are distant by $90 \mathrm{~km}$, it is not possible to correlate precisely the two sedimentary sections although the «La rambla del Font » section probably belongs to the upper part of Tortonian marls succession of Lorca.

The dolomite nodules of Lorca and Fortuna are often meter-thick bodies, sometimes with internal conduits, that exhibit rounded to elongated shapes (Fig. 3A, B, C). They have an external layered cortex and a relatively massive core with conchoidal fracture. Their yellowish hue makes them very distinguishable from the surrounding blue-grey marls.

A total of 16 samples was selected for the present study, corresponding to 4 massive dolomite nodules, 2 nodules (A and B) from Lorca and 2 nodules (C and D) from Fortuna for which previous isotope measurements gave high $\delta^{13} \mathrm{C}$ values, and to their nearby (close to the nodule contact to less than one meter away) surrounding marly sediments (Table 1). In Lorca, nodules $\mathrm{A}$ (the upper one, $1 \mathrm{~m} \mathrm{x} 0.6 \mathrm{~m}$ ) and $\mathrm{B}$ (the lower one, $1 \mathrm{~m} \times 0.4 \mathrm{~m}$ ) are very close and separated by $50 \mathrm{~cm}$ of marls. In Fortuna, nodules $\mathrm{C}(2 \mathrm{~m} \mathrm{x} 1 \mathrm{~m})$ and D $(1 \mathrm{~m} \mathrm{x} 0.5 \mathrm{~m})$ are distant by $13 \mathrm{~m}$ (Fig. 2). The samples from Lorca belong to the upper main horizon of dolomite nodules that is located about 200 meters below the boundary between the Tortonian marls and the lower Messinian Tripoli formation (Pierre and Rouchy, 2004). The samples from Fortuna are from a marly sequence with abundant dolomite nodules that might be equivalent to the main horizon of Lorca.

Each sample was crushed in an agate mortar to make a homogeneous powder that was used for mineralogical, geochemical and isotopic analyses.

\section{$\underline{\text { 3- Methods }}$}




\subsection{Mineralogy}

About one gram of the powdered sample was reacted with $1 \mathrm{~N}$ acetic acid at room temperature. The remaining sediment was washed with distilled water, dried and weighted thus allowing to obtain the total quantitative weight $\%$ of carbonate. The sample powder before and after acid acetic attack was analyzed by X-ray diffraction (XRD) as randomly oriented powder. The phase composition of the samples was identified by XRD at the Muséum National deeHistoire Naturelle (Paris), with a Brüker AXS D2 PHASER Desktop Diffractometer with a linear detector LYNXEYE, $\mathrm{Cu}-\mathrm{K} \alpha$ radiation $(\lambda=0.15406 \AA)$ and $\mathrm{Ni}$ filter at $30 \mathrm{kV}$ and $10 \mathrm{~mA}$. The $\mathrm{d}_{104}$ values of calcite and dolomite were used to evaluate their stoichiometry (standard values: $3.035 \AA$ for calcite, and $2.886 \AA$ for dolomite). The relative mol\% $\mathrm{MgCO}_{3}$ content in the crystal lattice of calcite can be estimated using a linear interpolation between interplanar spacings as experimentally observed by Goldsmith et al. (1961). However this method was not used to estimate dolomite composition, as the position of the $\mathrm{d}_{104}$ peak depends on the incorporation of various cations $(\mathrm{Mg}, \mathrm{Ca}, \mathrm{Fe}, \mathrm{Mn})$ into the crystal lattice. XRD diffractograms of randomly oriented powders (bulk sediments and acidacetic residues) were collected over the angular range $3^{\circ} \leq 2 \theta \leq 65^{\circ}$, with a step increment of $0.02^{\circ}$ and a counting time of $0.2 \mathrm{~s}$ per step.

In preparation for mineralogical analyses of the clay fraction, the acid acetic treated sample was washed several times, and the fine fraction obtained by settling in a water column and centrifugation. XRD routine standard analysis of the $<2 \mu \mathrm{m}$ fraction was run on three types of oriented aggregates collected on glass slides. In order to distinguish between the main clay phases, the same sample preparation was analysed after i) Air-drying, ii) Ethylene-glycol solvation, and iii) heating at $490{ }^{\circ} \mathrm{C}$, following international procedure (Moore and Reynolds, 1997). X-ray diffractograms of $\leq 2 \mu \mathrm{m}$ oriented preparations were collected over the angular range $2.5^{\circ} \leq 2 \theta \leq 40^{\circ}$, with a step increment of $0.01^{\circ}$ and an interval time of $0.2 \mathrm{~s}$ per step for each run. Clay minerals were identified using the position of the main reflections on the three XRD runs (Brown and Brindley, 1980). Quantification of each clay mineral assemblage was classically determined from glycolated run diffractograms. Measurements of the area of (001) peaks were achieved using the MacDiff 4.2.5 software (Petschick, 2000). The integrated areas were multiplied by weighting factors (Biscaye, 1965) and normalized to $100 \%$. The results remain semi-quantitative and are not always consistent as there was not always enough material to smear a homogeneous clay paste onto a glass slide. The oriented clay mineral 
preparations done allowing a thin dispersion to dry slowly on a glass slide are more or less particle-size segregated with the finest material on the top.

Scanning electron microscope (SEM) observations were performed on small fragments of samples (marls and nodules) at the ISTEP (Institut des Sciences de la Terre de Paris of the Université Pierre et Marie Curie (Paris), to identify the morphology of carbonate minerals and their relationship with the other sedimentary components (biogenic particles, detrital minerals, clay minerals, pyrite).

\subsection{Elemental geochemistry}

The elemental geochemistry of major elements was realized by wavelength dispersive X-ray fluorescence (WD-XRF) using the fully automated S8 Tiger Brüker sequential X-ray spectrometer at the «Département de Géosciences Marines» at Ifremer (Brest). Quantitative elemental concentrations were performed from their $\mathrm{K} \alpha$ lines under vacuum on sample in rotation. Analytical parameters and time measurements were optimized.

Samples were prepared according to a slightly modified conventional fusion method for WD-XRF analysis previously described (El Maghraoui et al, 1999). First, the bulk sediment powder was dried overnight at $105^{\circ} \mathrm{C}$ and then calcinated from ambient temperature to $1050^{\circ} \mathrm{C}$ for 15 minutes under air. Loss on ignition (LOI) was determined by precise weighing. To make the glass discs, one $0.5 \mathrm{~g}$ aliquot of calcinated sample was weighed precisely and mixed with $9.000 \mathrm{~g}$ of spectroflux $120 \mathrm{~A}\left(90 \% \mathrm{Li}_{2} \mathrm{~B}_{4} \mathrm{O}_{7}-10 \% \mathrm{LiF}\right)$ distributed by Johnson Matthey and $500 \mu \mathrm{l}$ of $250 \mathrm{~g}^{-1}$ solution of $\mathrm{LiBr}$ from ACROS as no-wetting agent was added. The fusion was performed in a Pt-Au crucible at $1050^{\circ} \mathrm{C}$ placed in a muffle furnace. The dilution of the sample in the flux avoids matrix effects and provides homogeneous glassdisks. Characteristic element line net intensities were correlated with certified concentrations for a set of international reference materials to elaborate linear calibration curves. The analytical absolute precision is better than $0.5 \%$ for all major elements. Major elements $\left(\mathrm{SiO}_{2}, \mathrm{Al}_{2} \mathrm{O}_{3}, \mathrm{CaO}, \mathrm{MgO}, \mathrm{Fe}_{2} \mathrm{O}_{3}, \mathrm{MnO}, \mathrm{Na}_{2} \mathrm{O}, \mathrm{K}_{2} \mathrm{O}, \mathrm{P}_{2} \mathrm{O}_{5}, \mathrm{TiO}_{2}, \mathrm{SO}_{3}\right)$ were determined during a single run. The results $(\mathrm{m} / \mathrm{m})$ are reported in Table 1 (dry basis, $105^{\circ} \mathrm{C}$ ).

\subsection{Oxygen and carbon stable isotopes}

The stable oxygen and carbon isotopic analyses were realized on the powder of bulk sediment. Between 50 and $200 \mathrm{mg}$ of sediment (depending on its carbonate content) was reacted at $25^{\circ} \mathrm{C}$ with $100 \%$ phosphoric acid, with a reaction time of one day or three days for 
samples containing calcite or dolomite respectively, and the $\mathrm{CO}_{2}$ produced during the reaction was extracted offline in a vacuum line. For two samples with mixtures of calcite and dolomite (Es-98-2-26 and Es-98-2-29), a two-step $\mathrm{CO}_{2}$ extraction procedure modified from Clayton et al. (1968) was applied: the $\mathrm{CO}_{2}$ extracted after 20 minutes of reaction was considered to come solely from calcite whereas the $\mathrm{CO}_{2}$ extracted after three more days of pursued reaction was considered as derived from dolomite. The $\mathrm{CO}_{2}$ gas was then analyzed with a triple collector dual inlet isotopic ratio mass spectrometer (DI-IRMS-Isogas Sira 9) at LOCEAN (Université Pierre et Marie Curie, Paris). The isotopic compositions are expressed in the conventional $\delta$ notation relative to the Vienna Peedee Belemnite (VPDB) reference (Craig, 1957; Gonfiantini et al., 1995).

$\delta=[(\mathrm{Rs} / \mathrm{Rr})-1] \times 1000$, where $\mathrm{R}={ }^{18} \mathrm{O} /{ }^{16} \mathrm{O}$ or ${ }^{13} \mathrm{C} /{ }^{12} \mathrm{C}$ respectively in the sample $\mathrm{s}$ and in the reference $\mathrm{r}$.

The analytical precision is $0.01 \%$ for both $\delta^{18} \mathrm{O}$ and $\delta^{13} \mathrm{C}$ values; the reproducibility of the carbonate reference run on separate days is $\pm 0.05 \%$ for $\delta^{18} \mathrm{O}$ and $\pm 0.02 \%$ for $\delta^{13} \mathrm{C}$.

\section{Results}

\subsection{Mineralogy}

All XRD results are presented in Table 1 and in figures $4 \mathrm{~A}$ and $\mathrm{B}$.

The total carbonate content of the dolomite nodules makes up from 70 to $88 \mathrm{wt} \%$ of the bulk sediment. The mineralogical composition of carbonate nodules (samples Es-98-2-27, Es-98-2-28, Es-98-2-32, Es-98-2-33, Es-06-73, Es-06-75, Es-06-94) is essentially dolomite except in the cortex of nodule-D of Fortuna (sample Es-06-95) that contains a mixture of dolomite and calcite. The $\mathrm{d}_{104}$ values of dolomites vary in the range 2.894-2.900 $\AA$ indicating ferroan composition close to the $\mathrm{d}_{104}$ value of $2.899 \AA$ of the ferroan dolomite $\left[\mathrm{Ca}\left(\mathrm{Mg}_{0.67}, \mathrm{Fe}_{0.33}\right)\left(\mathrm{CO}_{3}\right)_{2}\right]$ ASTM reference for XRD. This authigenic dolomite cements siliciclastic minerals where quartz and other silicates (mostly clay minerals and minor albite) represent respectively 6 to $16 \mathrm{wt} \%$ and 3 to $22 \mathrm{wt} \%$ of the bulk sediment (Fig. 4A).

In the surrounding marls, the total carbonate content is lower in Lorca (20 to $43 \mathrm{wt} \%$, samples Es-98-2-26, Es-98-2-29, Es-98-2-30, Es-98-2-31) than in Fortuna (54 to $55 \mathrm{wt} \%$, samples Es-06-75, Es-06-96, Es-06-97); it mostly consists of stoichiometric calcite mixed with various amount of dolomite that is made generally by a mixture of two dolomites, a 
stoichiometric dolomite and a ferroan dolomite with $d_{104}$ values in the range 2.886-2.902 $\AA$.

Quartz and other silicates (mostly clay minerals, minor albite and muscovite) represent respectively 9 to $22 \mathrm{wt} \%$ (except sample Es-98-2-31 with $43 \mathrm{wt} \%$ ) and 36 to $46 \mathrm{wt} \%$ of the bulk sediment (Fig. 4A).

A special attention was focused on the clay minerals that consist of mixtures of illite, chlorite and smectite, and show important differences in their abundance in the «other silicates » group where they are the dominant component (Fig. 4A) but a relative constancy of their assemblages (Fig. 4B) in the dolomite nodules (core and cortex) and the marls.

SEM observations show that the calcite component of the marls is biogenic, mostly coccoliths sometimes well preserved in coccospheres or partly dissolved (Fig. 5A, B). The coccoliths are very rare although well preserved in the dolomite nodules. The dolomite nodules are made of small (2 to $10 \mu \mathrm{m}$ ) interlocking dolomite rhombs (Fig. 5C, D, E, F, G) which euhedral crystal habit indicates that they are authigenic carbonates precipitated in the pore spaces of sediments. The dolomite crystals sometimes exhibit micron sized lacuna, which are interpreted as molds of clay particles (Fig. 5H). Framboids and octahedron of pyrite are very frequent both in dolomite nodules and marls (Fig. 5B, C, D, E, F). Gypsum occurs also occasionally as isolated corroded crystals in the marls (not shown in the figures).

\subsection{Elemental geochemistry}

The variations of the geochemical composition of the marls and dolomite nodules are presented in diagrams where the quantitative $\mathrm{wt} \%$ of elements is compared to the quantitative $\mathrm{wt} \%$ of total carbonate (Fig. 6A, B, C). All diagrams show linear regressions with high correlation coefficients $\left(\mathrm{R}^{2} \geq 0.98\right.$, except for $\mathrm{Na}_{2} \mathrm{O}$ where $\left.\mathrm{R}^{2}=0.42\right)$.

The LOI variation (from $12.56 \%$ to $40.66 \%$ ) is related to pyrolysis of organic matter and hydrated minerals and of the carbonates. The LOI due to $\mathrm{CO}_{2}$ release during carbonate pyrolysis differs significantly for calcite (44\%), stoichiometric dolomite $(47.8 \%)$ and for ferroan dolomite $\left(45.27 \%\right.$ for a composition $\left.\left[\mathrm{Ca}\left(\mathrm{Mg}_{0.67}, \mathrm{Fe}_{0.33}\right)\left(\mathrm{CO}_{3}\right)_{2}\right]\right)$ due the difference in their molecular weight $(100,92,97.20$ respectively). The LOI values of the two end members at $0 \%$ and $100 \%$ of carbonate calculated from the regression equation (Fig. $6 \mathrm{~A}$ ) are $3.73 \%$ and $45.86 \%$ respectively. The calculated LOI value of the carbonate end member is thus intermediate between the theoretical values of stoichiometric and ferroan dolomites. 
The major elements belonging to the silicate minerals ( $\mathrm{Si}, \mathrm{Al}, \mathrm{K}, \mathrm{Na}$ ) show linear distributions between the marly sediments and dolomite nodules, which indicate the progressive dilution of these elements by the increasing fraction of precipitated carbonate (Fig. $6 \mathrm{~B})$. There is no distinct variation of Fe between the marls and the nodules (Table 1).

The major elements belonging mostly to the carbonate minerals $(\mathrm{Mg}, \mathrm{Ca})$ show a linear enrichment as the carbonate content increases; the $(\mathrm{MgO}+\mathrm{CaO})$ concentrations of the silicate and carbonate end members calculated at $0 \%$ and $100 \%$ of carbonate from the regression equation (Fig. 6C) are respectively 5.47\% and 48.90\%, The slight dispersion of the points around the empirical regression line may be explained by the various contributions of calcite, stoichiometric and ferroan dolomites which have $(\mathrm{MgO}+\mathrm{CaO})$ concentration of $56 \%, 52.2 \%$ and $42.6 \%$ respectively. This distribution shows also that the $(\mathrm{MgO}+\mathrm{CaO})$ content was progressively concentrated in the newly formed dolomite mineral up to a factor of $\sim 8.9$ compared to the $(\mathrm{MgO}+\mathrm{CaO})$ content of the silicate end member in the marls.

\subsection{Oxygen and carbon stable isotopes}

The ranges of $\delta^{18} \mathrm{O}$ and $\delta^{13} \mathrm{C}$ values differ significantly in the marls where calcite dominates and in the dolomite nodules, defining clearly two groups of values (Table 1, Fig. 7).

In the marls, calcite is characterized by slightly negative isotopic compositions $(-2.40<$ $\left.\delta^{18} \mathrm{O}<-0.22,-1.26<\delta^{13} \mathrm{C}<-0.31\right)$ whereas dolomite exhibits higher oxygen isotopic compositions but similar carbon isotopic compositions $\left(+0.20<\delta^{18} \mathrm{O}<+0.86,-1.69<\delta^{13} \mathrm{C}<\right.$ $+0.46)$.

In the dolomite nodules, typically, the core exhibits the highest isotopic values $(+2.35<$ $\left.\delta^{18} \mathrm{O}<+4.32,+6.72<\delta^{13} \mathrm{C}<+7.88\right)$ whereas their cortex displays generally lower isotopic values $\left(+0.08<\delta^{18} \mathrm{O}<+0.81,+3.33<\delta^{13} \mathrm{C}<+5.73\right)$ except for nodule (C) where the cortex and the core display only slight differences of their isotopic values $\left(\delta^{18} \mathrm{O}=+2.79\right.$ and +2.35 , $\delta^{13} \mathrm{C}=+7.76$ and +6.72 respectively).

In fact, the $\delta^{18} \mathrm{O}$ and $\delta^{13} \mathrm{C}$ values of calcite and dolomite cannot be compared directly since the oxygen and carbon isotopic fractionation factors for calcite and dolomite are different, dolomite being enriched by 3 to $4 \%$ in ${ }^{18} \mathrm{O}$ and by $2 \%$ in ${ }^{13} \mathrm{C}$ relative to calcite that would precipitate in the same sedimentary conditions (Fritz and Smith, 1970, Matthews and Katz, 1977, Sheppard and Schwarcz, 1970). The most prominent difference between the two 
groups is thus the significant ${ }^{13} \mathrm{C}$ enrichment of dolomite in the nodules compared to the slightly negative $\delta^{13} \mathrm{C}$ values of calcite and dolomite in the marls.

\section{$\underline{\text { 5-Discussion }}$}

The clay minerals composition of marls and dolomite nodules of Spain does not display significant differences, which means that the whole sequence of methanogenic sediments was affected by the clay minerals diagenesis. In the dolomite nodules, it was shown that calcite (i.e. coccoliths) was almost totally dissolved and that clay minerals were also probably largely dissolved during these diagenetic reactions. These diagenetic processes were controlling the redistribution of major elements between the marls and the dolomite nodules, with no external contribution by circulating fluids.

The oxygen and carbon isotopic compositions of calcite from the marls are compatible with the marine origin of the calcite components (i.e. mostly coccoliths).

In two marly samples (Es-98-2-26 and Es-98-2-29) the $\delta^{18} \mathrm{O}$ values of coexisting dolomite and calcite differ by 2 and 3\%o respectively; these values are very close to the oxygen isotopic fractionation between these two minerals, which indicates that calcite and dolomite were precipitated with relatively similar conditions of sedimentary temperature and oxygen isotopic composition of water (i.e. surface seawater for coccoliths and pore water issued from bottom seawater with no contribution of another source of water during dolomite precipitation). The $\delta^{13} \mathrm{C}$ values of dolomite are lower by about $1 \%$ (in fact by $3 \%$ o taking account for the carbon isotopic fractionation between dolomite and calcite) compared to those of the coexisting calcite; this can be explained by a minor contribution of ${ }^{13} \mathrm{C}$-depleted DIC from organic matter remineralization in the pore solutions where this dolomite precipitated.

The dolomite nodules of Lorca and Fortuna were obviously formed in diagenetic conditions of active methanogenesis, as indicated by their highly positive $\delta^{13} \mathrm{C}$ values. The range of $\delta^{18} \mathrm{O}$ values of dolomite indicates precipitation under sedimentary conditions and thus rules out the possibility of any contribution of warm diagenetic fluids. Moreover the ${ }^{18} \mathrm{O}$ and ${ }^{13} \mathrm{C}$ enrichments by 2 to $4 \%$ between the core and the cortex of the nodules reflect probably local variations in the oxygen and carbon isotopic compositions of pore fluids during the growth of nodules. In sedimentary environments, ${ }^{18} \mathrm{O}$-rich pore fluids may be related to clay minerals dehydration or to gas hydrates decomposition (e.g. Aloisi et al., 2000, Dählmann and de Lange, 2003). In the dolomitic nodules of Spain, both processes could be 
proposed for the origin of the ${ }^{18} \mathrm{O}$-rich pore fluids from which the core of nodules precipitated: the smectite to illite transformation or the clay minerals dissolution might have released significant amounts of water in the pore fluids; episodic events of gas hydrates decomposition in the Lorca Basin were previously discussed by Pierre et al. (2002) and Pierre and Rouchy (2004).

The frequent occurrence of pyrite within the marls and dolomite nodules indicates strict anaerobic conditions where sulphate was reduced to hydrogen sulphide, further precipitated as pyrite depending on $\mathrm{Fe}^{2+}$ availability. The AOM reaction (described in the introduction) occurs in the sulphate-methane transition zone (SMTZ) where the sulphate is provided by the downward advection/diffusion of seawater whereas $\mathrm{CH}_{4}$ diffuses upwards from the underlying methanogenesis zone. Part of the $\mathrm{H}_{2} \mathrm{~S}$ produced by AOM diffuses downwards in the methanogenesis zone where it is involved in a complex cryptic sulphur cycle driven by iron that was recently described in marine sediments from Aarhus Bay in Denmark (Holmkvist et al. 2011). This cryptic sulphur cycle appears as a realistic explanation for the association of pyrite with dolomite formed in the methanogenesis zone.

The carbonate and silicate weathering by $\mathrm{CO}_{2}$-rich pore solutions were also the chemical reactions that released the $\mathrm{Ca}^{2+}, \mathrm{Mg}^{2+}$ and $\mathrm{Fe}^{2+}$ cations and bicarbonate in the pore solutions where dolomite precipitated, as shown in the following reactions.

Carbonate $+\mathrm{CO}_{2}+\mathrm{H}_{2} \mathrm{O} \rightarrow$ cations $+\mathrm{HCO}_{3}^{-}$

Silicate $+\mathrm{CO}_{2}+\mathrm{H}_{2} \mathrm{O} \rightarrow$ clay minerals + cations + dissolved silica $+\mathrm{HCO}_{3}^{-}$

clay minerals $+\mathrm{CO}_{2}+\mathrm{H}_{2} \mathrm{O} \rightarrow$ cations + dissolved silica $+\mathrm{HCO}_{3}^{-}$

cations $\left(\mathrm{Ca}^{2+}, \mathrm{Mg}^{2+}+\mathrm{Fe}^{2+}\right)+2 \mathrm{HCO}_{3}^{-} \rightarrow(\mathrm{Ca}, \mathrm{Mg}, \mathrm{Fe}) \mathrm{CO}_{3}+\mathrm{CO}_{2}+\mathrm{H}_{2} \mathrm{O}$

There was thus a combination of biogeochemical processes acting together for releasing DIC and cations during the formation of the dolomite nodules of Lorca and Fortuna: the $\mathrm{CH}_{4}$ and $\mathrm{CO}_{2}$ issued from methanogenesis were used respectively for reducing sulphate during AOM above the SMTZ and for carbonate and silicate chemical weathering below the SMTZ. As a result, the $\delta^{13} \mathrm{C}$ values of DIC, and thus of the authigenic dolomites of the nodules, correspond to the ${ }^{13} \mathrm{C}$-rich $\mathrm{CO}_{2}$ used for carbonate and silicate weathering.

\section{6- Conclusions}


The aim of this study was to identify the sources of DIC and cations that led to the formation of ${ }^{13} \mathrm{C}$-rich dolomite nodules in the Tortonian marls of the Lorca and Fortuna basins.

Our results demonstrate that the source of DIC was related to methanogenesis by microbial fermentation of the sedimentary organic matter of the Tortonian marls; the byproducts of this reaction - $\mathrm{CH}_{4}$ and $\mathrm{CO}_{2}$ - were transformed in DIC by two reactions, respectively the anaerobic oxidation of methane in the sulphate-methane transition zone and the mineral chemical weathering in the methanogenesis zone where the authigenic dolomite precipitated. The latter reaction was also responsible for the release of cations in the pore solutions, the mineral sources being on the one hand $\mathrm{Mg}$-Fe rich silicates (i.e. chlorites, smectites) and on the other hand the sedimentary calcite. The clay minerals diagenesis and/or episodic events of gas hydrate dissociation were also the possible sources of ${ }^{18} \mathrm{O}$-rich water in the pore solutions where dolomite precipitated.

\section{$\underline{\text { Acknowledgements }}$}

We wish to thank the guest editors of this special issue for supporting us to publish these results. We are also grateful to the two anonymous reviewers for their very constructive comments that helped us to improve the manuscript.

\section{$\underline{\text { References }}$}

Aiello I.W., 2005. Fossil Seep Structures of the Monterey Bay Region and Tectonic/Structural Controls on Fluid Flow in an Active Transform Margin. In: Geobiology of Ancient and Modern Methane-Seeps. J. Peckman and J. Goedert (Eds.). Palaeogeogr., Palaeoclim., Palaeoecol.. 227, 124-142.

Aloisi, G., Pierre, C., Rouchy, J-M., Foucher, J-P., Woodside, J. and the MEDINAUT Scientific Party, 2000. Methane-related authigenic carbonates of eastern Mediterranean Sea mud volcanoes and their possible relation to gas hydrate destabilisation. Earth Planet. Sc. Lett. $5675,1-18$.

Bayon, G., Pierre, C., Etoubleau, J., Voisset, M., Cauquil, E., Marsset, T., Sultan, N., Le Drezen, E., Fouquet, Y., 2007. $\mathrm{Sr} / \mathrm{Ca}$ and $\mathrm{Mg} / \mathrm{Ca}$ ratios in Niger Delta sediments : Implications for authigenic carbonate genesis in cold seep environments. Mar. Geol. 241, 93109. 
Biscaye, P.E., 1965. Mineralogy and sedimentation of recent deep-sea clays in the Atlantic Ocean and adjacent seas and oceans. Geol. Soc. Am. Bull. 76, 803-831.

Boetius, A., Ravenschlag, K., Schubert, C.J., Rickert, D., Widdel, F., Gieseke, A., Amann, R., Jorgensen, B.B., Witte, U., Pfannkuche, O, 2000. A marine consortium apparently mediating anaerobic oxidation of methane. Nature. 407, 623-626.

Bohrmann, G., Greinert, J., Suess, E., Torres, M., 1998. Authigenic carbonates from the Cascadia subduction zone and their relation to gas hydrate stability. Geology. 26, 647-650.

Brown, G., Brindley, G.W., 1980. X-ray diffraction procedures for clay mineral identification. In: Brindley, G.W., Brown, G. (Eds.), Crystal Structures of Clay Minerals and their X-ray Identification. Mineralogical Society, London, pp. 305-359.

Campbell, K.A., Farmer, J.D., Des Marais, D., 2002. Ancient hydrocarbon seeps from the Mesozoic convergent margin of California: carbonate geochemistry, fluids and paleoenvironments. Geofluids. 2, 63-94.

Capozzi, R., Guido, F., Oppo, D., 2012. Methane-derived authigenic carbonates (MDAC) in northern-central Adriatic Sea: Relationships between reservoir and methane seepages. Mar. Geol. 332-334, 174-188.

Claypool, G.E., Kaplan, I.R., 1974. The origin and distribution of methane in marine sediments. In : IR Kaplan (Editor), Natural Gases in Marine Sediments, Plenum, New York, NY, pp 99-139

Claypool, G.E., Threlkeld, C.N., 1983. Anoxic diagenesis and methane generation in sediments of the Blake Outer Ridge, Deep Sea Drilling Project Site 533, Leg 76. In: Sheridan, R.E., Gradstein, F.M., et al., Init. Repts. DSDP, 76: Washington (U.S. Govt. Printing Office), pp. 391- 402.

Clayton, R.N., Jones, B.F., Berner, R.A., 1968. Isotopic study of dolomite formation under sedimentary conditions. Geochim. Cosmochim. Acta. 32, 415-432.

Craig, H., 1957. Isotopic standards for carbon and oxygen and correction factors for massspectrometric analysis of carbon dioxide. Geochim. Cosmochim. Acta. 12,133-149. 
Crémière, A., Pierre, C., Blanc-Valleron, M-M., Zitter, T., Cagatay, N., Henry P. 2012. Methane-derived authigenic carbonates along the North Anatolian fault system in Sea of Marmara (Turkey). Deep Sea Res. I. 66,114-130 DOI 10.1016/j.dsr.21012.03.014

Curtis, C.D., Coleman, M.L., 1986. Controls on the precipitation of early diagenetic calcite,, dolomite and siderite nodules in complex depositional sequences. Soc. Econ. Paleont. Mineral. 23-33.

Dählmann A., de Lange G.J., 2003. Fluid-sediment interactions at Eastern Mediterranean mud volcanoes : a stable isotope study from ODP Leg 160. Earth Planet. Sci. Lett., 212, 377-391.

El Maghraoui, M., Joron, J.L., Etoubleau, J., Cambon, P., Treuil, M., 1999. Determination of Forty Four Major and Trace Elements in GPMA Magmatic Rock Reference Materials using X-ray Fluorescence Spectrometry (XRF) and Instrumental Neutron Activation Analysis (INAA). Geostandards Newsletter. 23,1-06,56-68

Fritz, P., Smith, D.G.W., 1970. The isotopic composition of secondary dolomites. Geochim. Cosmochim. Acta. 34,1161-1173.

Goldsmith, J.R., Graf, D.L., Heard, H.C., 1961. Lattice constants of the calcium-magnesium carbonates. Amer. Mineral. 46, 453-457.

Gonfiantini, R., Stichler, W., Kozanski, K., 1995. Standards and intercomparison materials distributed by the International Atomic Energy Agency for stable isotope measurements. In: Reference and Intercomparison Materials for Stable Isotopes of Light Elements, IAEATECDOC-825, IAEA, Vienna, pp 13-29.

Hinrichs, K.U., Summons, R.E., Orphan, V., Sylva, S.P., Hayes, J.M., 2000. Molecular and isotopic analysis of anaerobic methane-oxidizing communities in marine sediments. Org. Geochem. 31,1685-1701.

Holmkvsit L., Ferdelman T.G., Jorgensen B.B., 2011. A cryptic sulfur cycle driven by iron in the methane zone of marine sediment (Aarhus Bay, Denmark). Geochim. Cosmochim. Acta. 75, 3581-3599.

Irwin, H., Curtis, C., Coleman, M., 1977. Isotopic evidence for source of diagenetic carbonates formed during burial of organic-rich sediments. Nature. 269, 209-213. 
Kelts, K., McKenzie, J.A., 1982. Diagenetic dolomite formation in Quaternary anoxic diatomaceous muds of DSDP Leg 64, Gulf of California. In: I. Curray, D. Moore et al., In. Rep. DSDP; 64. U.S. Government Printing Office, Washington, D.C., pp. 553-569.

Matthews, A., Katz, A., 1977. Oxygen isotope fractionation during the dolomitization of calcium carbonate. Geochim. Cosmochim. Acta. 41,1461-1438.

Moore, D.M., Reynolds, R.C., 1997. X-Ray Diffraction and the Identification and Analysis of Clay Minerals. Oxford University Press, New York, 378 pp.

Orphan, V.J., House, C.H., Hinrichs, K.U., McKeegan, K.D., DeLong, E.F., 2001. Methaneconsuming archea revealed by directly coupled isotopic and phylogenetic analysis. Science. 293, 484-487.

Peckmann, J., Reimer, A., Luth, C., Hansen, B.T., Heinicke, C., Hoefs, J., Reitner, J., 2001. Methane-derived carbonate and authigenic pyrite from the northwestern Black Sea. Mar. Geol. $1-2,129-150$.

Petschick, R.2000. MacDiff4.2.2. http://servermac.geologie.unfrankfurt.de/Rainer.html.

Pierre, C., Rouchy, J-M., Blanc-Valleron, M-M., 2002. Gas hydrate dissociation in the Lorca Basin (SE Spain) during the Mediterranean salinity crisis. Sedim. Geol. 147, 247- 252.

Pierre, C., Rouchy, J-M., 2004. Isotopic compositions of diagenetic dolomites in the Tortonian marls of the Western Mediterranean margins: evidence of past gas hydrate formation and dissociation. Chem. Geol. 205, 469-484. Doi : 10.1016/j.chemgeo.2003.12.026

Pierre, C., Blanc-Valleron, M-M., Demange, J., Boudouma, O., Foucher, J-P., Pape, T., Himmler, T., Fekete, N., Spiess, V., 2012. Authigenic carbonates from active methane seeps offshore south-west Africa. Geo-Marine Lett. 32, 501-513. DOI 10.1007/s00367-012-0295-x

Pierre, C., Blanc-Valleron, M-M., Caquineau, S., März, C., Ravelo, A.C., Takahashi, K., Alvarez-Zarikian, C., 2014. Mineralogical, geochemical and isotopic characterization of authigenic carbonates from the methane-bearing sediments of the Bering Sea continental margin (IODP Expedition 323, Sites U1343-1345). Deep-Sea Res.II. http://dx.doi.org/10.1016/j.dsr2.2014.03.011

Roberts, H.H., Feng, D., Joye, S.B., 2010. Cold-seep carbonates of the middle and lower continental slope, northern Gulf of Mexico. Deep Sea Res. II, 57, 2040-2054. 
Rosenfeld W.D., Silverman S.R., 1959. Carbon isotope fractionation in bacterial production of methane. Science 130, 1658-1659.

Sheppard S.M.F., Schwarcz H.P., 1970. Fractionation of carbon and oxygen isotopes and magnesium between coexisting metamorphic calcite and dolomite. Contrib. Mineral. Petrol., 26, 161-198.

Wallmann, K., Aloisi, G., Haeckel, M., Tishchenko, P., Pavlova, G., Greinert, J., Kutterolf, S., Eisenhauer, A., 2008. Silicate weathering in anoxic marine sediments. Geochim. Cosmochim. Acta, 72, 2895-2918.

Wehrmann L.M., Risgaard-Petersen N., Schrum H.N., Walsh E.A., Huh Y., Ikehara M., Pierre C., D`Hondt S., Ferdelman T.G., Ravelo A.C., Takahashi K., Alvarez-Zarikian C., and the Integrated Ocean Drilling Program Expedition 323 Scientific Party, 2011. Coupled organic and inorganic carbon cycling in the deep subseafloor sediment of the northeast Bering Sea Slope (IODP Exp. 323). Chem. Geol., 284, 251-261. 


\section{$\underline{\text { Figures captions }}$}

Figure 1 : Simplified geological map of southern Spain with location of the Lorca and Fortuna Basins.

Figure 2: Distribution of the dolomite nodules in the Tortonian marls of the Fortuna Basin (Rambla del Font section) with location of the studied samples. Original dip was 15 to $40^{\circ} \mathrm{W}$. The dashed lines represent the stratification of the marly layers.

Figure 3 : A- Lorca Basin : Dolomite nodules within the Tortonian marls; B- Fortuna Basin : Close-up view of a dolomite nodule embedded in the blue-grey marls, showing a massive core surrounded by a layered cortex; C - Lorca Basin : Close-up view of a dolomite nodule with an internal conduit; the surrounding marls display numerous veins filled with secondary gypsum.

Figure 4 : A-Composition of the main minerals (in relative weight \%) in the marls (black labels), the cortex of nodules (blue labels) and the core of nodules (blue bold labels) of Lorca and Fortuna. B- Composition of the clay minerals (in relative \%) in the marls (black labels), the cortex of nodules (blue labels) and the core of nodules (blue bold labels) of Lorca and Fortuna.

Figure 5 : SEM photographs of the dolomite nodules and surrounding marls. A- Fortuna-Es06-75 : marls with detrital silicates, clay minerals, coccoliths; B- Lorca-Es-98-2-29 : marls with clay minerals, rare coccoliths, pyrite framboids ; C- Lorca-Es-98-2-28 : core of the dolomite nodule with euhedral dolomite rhombs, some of them coated with pyrite ,duste, one pyrite framboid at the bottom left corner; D- Lorca- Es-98-2-28: core of the dolomite nodule with interlocked euhedral dolomite rhomb, one pyrite aggregate associated with the larger rhombs ; E- Fortuna- Es-06-73 : core of the nodule with euhedral dolomite rhombs and pyrite octahedrons; F- Fortuna- Es-06-73 : core of the nodule with interlocked euhedral dolomite rhombs and a cluster of pyrite octahedrons; G- Lorca-Es-98-2-27 : cortex of the nodule with interlocked dolomite rhombs; H- Lorca-Es-98-2-27 : cortex of the nodule with a close-up photograph showing dolomite rhombs with small lacunas.

Figure 6: Elemental geochemistry (XRF measurements) of the dolomite nodules (filled symbols) and surrounding marls (open symbols) of the Lorca Basin (squares) and Fortuna Basin (circles). A- Relation between the Loss On Ignition (LOI) and the total carbonate content (absolute wt\% carbonate); B- Relation between the major elements of silicate minerals ( $\mathrm{Si}, \mathrm{Al}, \mathrm{K}, \mathrm{Na}$ ) and the total carbonate content (absolute wt\% carbonate); C- 
Relation between the major elements of carbonates $(\mathrm{Ca}$ and $\mathrm{Mg})$ and the total carbonate content (absolute wt $\%$ carbonate).

Figure 7: Oxygen and carbon isotopic compositions of the carbonate from the dolomite nodules (filled circles for the Fortuna Basin, filled squares for the Lorca Basin) and from the surrounding marls (open circles for the calcite of the Fortuna Basin, open squares and rhombs for the calcite and the dolomite respectively of the Lorca Basin).

Table 1 caption : Mineralogical composition (absolute $\mathrm{wt} \%$ total carbonate, relative $\mathrm{wt} \%$ of quartz and silicates in the bulk sediment ; relative $\mathrm{wt} \%$ of smectite, illite, chlorite in the clay fraction, $\mathrm{d}_{104}$ values in $\AA$ of calcite and dolomite), oxygen and carbon isotopic compositions of carbonates $\left(\delta^{18} \mathrm{O}\right.$ and $\delta^{13} \mathrm{C}$ in \%o VPDB), and elemental composition (wt\%) of major elements of the marls and dolomite nodules of the Lorca and Fortuna Basins. 
Mineralogy and stable isotopes

\begin{tabular}{|c|c|c|c|c|c|c|c|c|c|c|c|c|c|c|c|c|}
\hline sample & facies & $\begin{array}{c}\text { relative \% } \\
\text { quartz }\end{array}$ & $\begin{array}{c}\text { relative } \% \\
\text { other silicates }\end{array}$ & $\begin{array}{l}\mathrm{w} t \% \text { total } \\
\text { carbonate }\end{array}$ & $\begin{array}{l}\text { relative \% } \\
\text { smectite }\end{array}$ & $\begin{array}{l}\text { relative } \% \\
\text { illite }\end{array}$ & $\begin{array}{l}\text { relative } \% \\
\text { chlorite }\end{array}$ & $\begin{array}{l}\text { relative } \% \\
\text { dolomite }\end{array}$ & $\begin{array}{l}\text { relative } \% \\
\text { calcite }\end{array}$ & $\begin{array}{l}\mathrm{d} 104 \\
\text { calcite }\end{array}$ & $\begin{array}{c}\text { d104 } \\
\text { dolomite } 1\end{array}$ & $\begin{array}{c}\text { d104 } \\
\text { dolomite } 2\end{array}$ & $\begin{array}{c}\delta^{18} \mathrm{O} \\
\text { dolomite }\end{array}$ & $\begin{array}{c}\delta^{13} \mathrm{C} \\
\text { dolomite }\end{array}$ & $\begin{array}{c}\delta^{18} \mathrm{O} \\
\text { calcite }\end{array}$ & $\begin{array}{c}\delta^{13} \mathrm{C} \\
\text { calcite }\end{array}$ \\
\hline \multicolumn{17}{|l|}{ LORCA } \\
\hline ES-98-2-26 & marls $5 \mathrm{~cm}$ above nodule (A) & 18 & 45 & 37 & 28 & 68 & 4 & 27 & 10 & 3.033 & 2.893 & 2.887 & +0.86 & -1.69 & -2.08 & -0.62 \\
\hline ES-98-2-27 & less indurated cortex of nodule (A) & 16 & 16 & 68 & 29 & 67 & 4 & 68 & 0 & & 2.899 & & +0.20 & +4.48 & & \\
\hline ES-98-2-28 & core of nodule (A) & 10 & 6 & 84 & 24 & 71 & 5 & 84 & 0 & & 2.894 & & +2.67 & +7.88 & & \\
\hline ES-98-2-29 & marls $5 \mathrm{~cm}$ below nodule (A) & 22 & 42 & 36 & 29 & 66 & 5 & 10 & 26 & 3.035 & 2.892 & & +0.29 & -1.51 & -1.78 & -0.43 \\
\hline ES-98-2-30 & marls at $25 \mathrm{~cm}$ of nodules (A) and (B) & 14 & 45 & 41 & 29 & 67 & 4 & 3 & 38 & 3.034 & 2.898 & 2.887 & & & -1.87 & -1.26 \\
\hline ES-98-2-31 & marls $5 \mathrm{~cm}$ above nodule (B) & 43 & 37 & 20 & 28 & 68 & 4 & 18 & 2 & 3.035 & 2.894 & 2.886 & +0.65 & +0.46 & & \\
\hline ES-98-2-32 & ochre cortex of nodule (B) & 10 & 13 & 77 & 27 & 69 & 4 & 77 & 0 & & 2.898 & & +0.81 & +5.73 & & \\
\hline ES-98-2-33 & core of nodule (B) & 10 & 7 & 83 & 27 & 68 & 5 & 83 & 0 & & 2.897 & & +4.32 & +7.12 & & \\
\hline ES-98-2-33bis & marls at $20 \mathrm{~cm}$ of nodule (B) & 15 & 42 & 43 & 24 & 70 & 6 & 4 & 39 & 3.034 & 2.902 & 2.887 & & & -0.22 & -1.02 \\
\hline \multicolumn{17}{|l|}{ FORTUNA } \\
\hline ES-06-73 & core of nodule (C) & 11 & 4 & 85 & 36 & 60 & 4 & 85 & 0 & & 2.894 & & +2.35 & +6.72 & & \\
\hline ES-06-74 & cortex of nodule $\mathbb{C}$ & 9 & 3 & 88 & 33 & 63 & 4 & 88 & 0 & & 2.895 & & +2.79 & +7.86 & & \\
\hline ES-06-75 & marls $15 \mathrm{~cm}$ above nodule $\odot$ & 10 & 35 & 55 & 28 & 67 & 5 & 5 & 50 & 3.034 & 2.899 & 2.887 & & & -2.4 & -0.5 \\
\hline ES-06-94 & core of nodule (D) & 8 & 8 & 84 & 32 & 63 & 5 & 81 & 3 & 3.033 & 2.897 & & +2.64 & +7.86 & & \\
\hline ES-06-95 & cortex of nodule (D) & 11 & 17 & 72 & 25 & 70 & 5 & 32 & 40 & 3.034 & 2.901 & & +0.08 & +3.33 & & \\
\hline ES-06-96 & marls at $30 \mathrm{~cm}$ above nodule (D) & 8 & 38 & 54 & 39 & 57 & 4 & 6 & 48 & 3.034 & 2.900 & 2.887 & & & -0.92 & -0.31 \\
\hline ES-06-97 & marls at $60 \mathrm{~cm}$ above nodule (D) & 9 & 37 & 54 & 35 & 61 & 4 & 4 & 50 & 3.033 & 2.899 & 2.890 & & & -0.72 & -0.56 \\
\hline
\end{tabular}

Elemental geochemistry

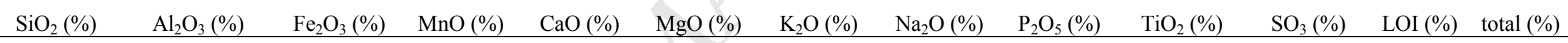

\begin{tabular}{l}
\multicolumn{1}{c}{ sample } \\
\hline LORCA \\
ES-98-2-26 \\
ES-98-2-27 \\
ES-98-2-28 \\
ES-98-2-29 \\
ES-98-2-30 \\
ES-98-2-31 \\
ES-98-2-32 \\
ES-98-2-33 \\
ES-98-2-33bis \\
FORTUNA \\
ES-06-73 \\
ES-06-74 \\
ES-06-75 \\
ES-06-94 \\
ES-06-95 \\
ES-06-96 \\
ES-06-97
\end{tabular}

marls $5 \mathrm{~cm}$ above nodule (A)
less indurated periphery of nodule (A)
core of nodule (A)
marls $5 \mathrm{~cm}$ below nodule (A)
marls at $25 \mathrm{~cm}$ of nodules (A) and (B)
marls $5 \mathrm{~cm}$ above nodule (B)
ochre cortex of nodule (B)
core of nodule (B)
marls at $20 \mathrm{~cm}$ of nodule (B)
core of nodule $\odot$
cortex of nodule $\odot$
marls $15 \mathrm{~cm}$ above nodule $\odot$
core of nodule (D)
cortex of nodule (D)
marls at $30 \mathrm{~cm}$ above nodule (D)
marls at $60 \mathrm{~cm}$ above nodule (D)

38.46
18.90
9.21
39.14
34.99
48.23
13.06
9.78
34.20
11.38
8.21
27.53
10.15
17.03
27.34
27.36

$\begin{array}{rrrrr}11.78 & 4.74 & 0.02 & 14.77 & 5.87 \\ 5.88 & 6.18 & 0.06 & 21.03 & 12.37 \\ 3.01 & 2.69 & 0.01 & 26.43 & 16.60 \\ 12.34 & 4.64 & 0.02 & 15.22 & 5.39 \\ 11.17 & 4.06 & 0.02 & 20.35 & 4.16 \\ 15.28 & 5.5 & 0.03 & 5.55 & 6.64 \\ 4.09 & 5.85 & 0.05 & 24.10 & 13.95 \\ 3.17 & 5.29 & 0.04 & 26.04 & 14.98 \\ 10.81 & 3.82 & 0.02 & 20.86 & 4.29 \\ & & & & \\ 3.57 & 2.34 & 0.01 & 25.64 & 16.13 \\ 2.73 & 2.28 & 0.01 & 27.15 & 16.94 \\ 8.44 & 3.08 & 0.02 & 26.27 & 3.58 \\ 3.32 & 4.77 & 0.02 & 26.53 & 14.60 \\ 5.19 & 4.26 & 0.03 & 27.86 & 9.48 \\ 8.15 & 3.21 & 0.02 & 27.26 & 3.59 \\ 8.42 & 3.02 & 0.02 & 27.50 & 3.30\end{array}$

$\begin{array}{ll}2.88 & 0.83 \\ 1.09 & 0.56 \\ 0.45 & 0.28 \\ 3.06 & 0.63 \\ 2.79 & 0.54 \\ 3.88 & 1.0 \\ 0.67 & 0.43 \\ 0.64 & 0.2 \\ 2.55 & 0.69 \\ & \\ 0.67 & 0.49 \\ 0.50 & 0.4 \\ 1.64 & 1.43 \\ 0.66 & 0.19 \\ 1.17 & 0.31 \\ 1.82 & 0.59 \\ 1.99 & 0.45\end{array}$

$\begin{array}{rrrrr}0.14 & 0.56 & 0.07 & 19.65 & 99.77 \\ 0.11 & 0.28 & 0.19 & 32.99 & 99.66 \\ 0.09 & 0.14 & 0.16 & 40.56 & 99.64 \\ 0.15 & 0.59 & 0.09 & 18.81 & 100.09 \\ 0.13 & 0.52 & 0.11 & 20.97 & 99.82 \\ 0.17 & 0.72 & 0.08 & 12.56 & 99.69 \\ 0.09 & 0.20 & 0.33 & 37.05 & 99.88 \\ 0.09 & 0.15 & 0.04 & 39.32 & 99.77 \\ 0.13 & 0.50 & 0.21 & 21.94 & 100.02 \\ & & & & \\ 0.10 & 0.16 & 0.8 & 38.67 & 99.96 \\ 0.09 & 0.12 & 0.68 & 40.66 & 99.79 \\ 0.15 & 0.39 & 1.28 & 25.95 & 99.76 \\ 0.11 & 0.15 & 0.52 & 38.82 & 99.85 \\ 0.11 & 0.24 & 0.75 & 33.48 & 99.91 \\ 0.15 & 0.38 & 0.68 & 26.35 & 99.54 \\ 0.16 & 0.38 & 0.93 & 25.9 & 99.50\end{array}$




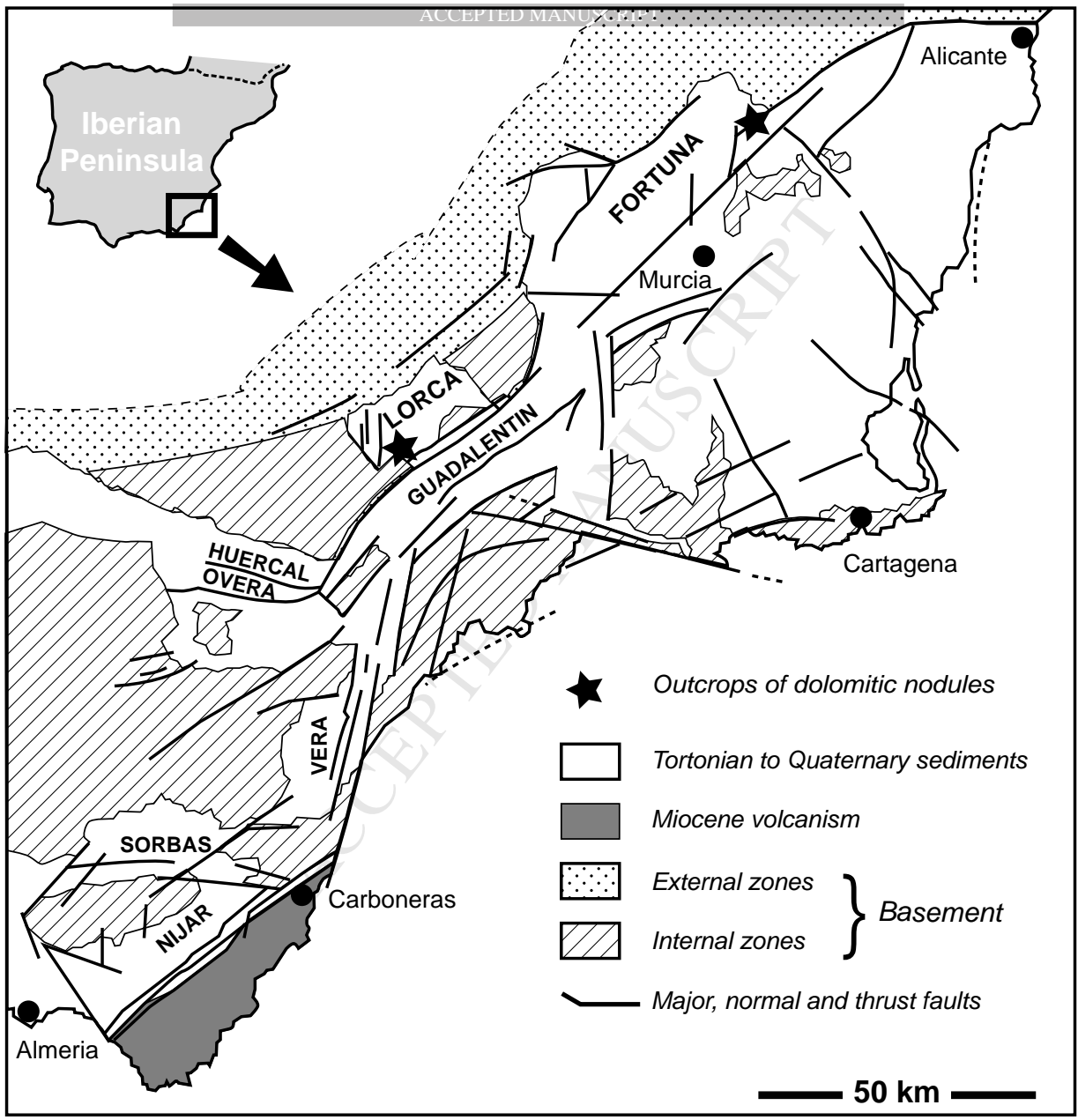




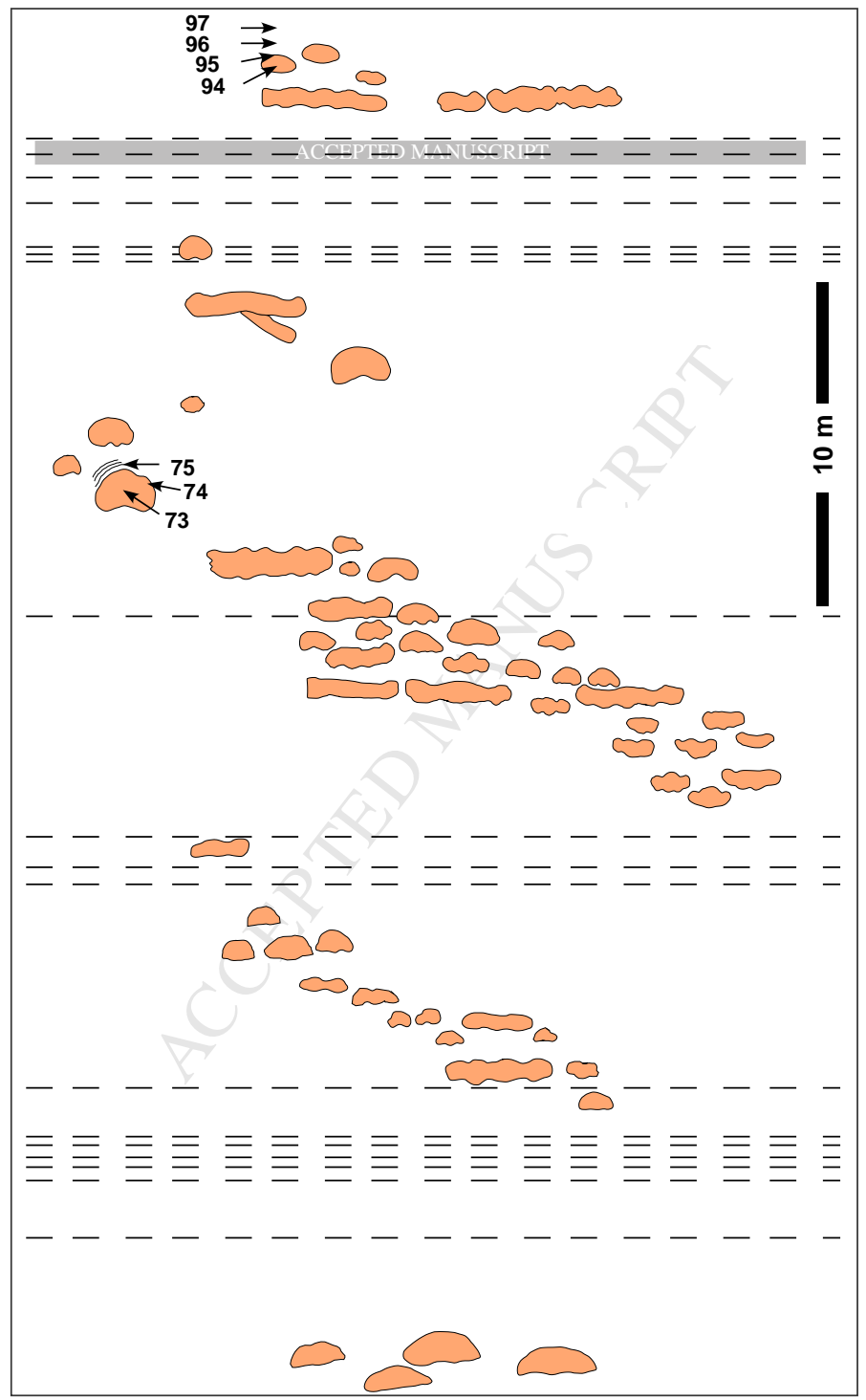



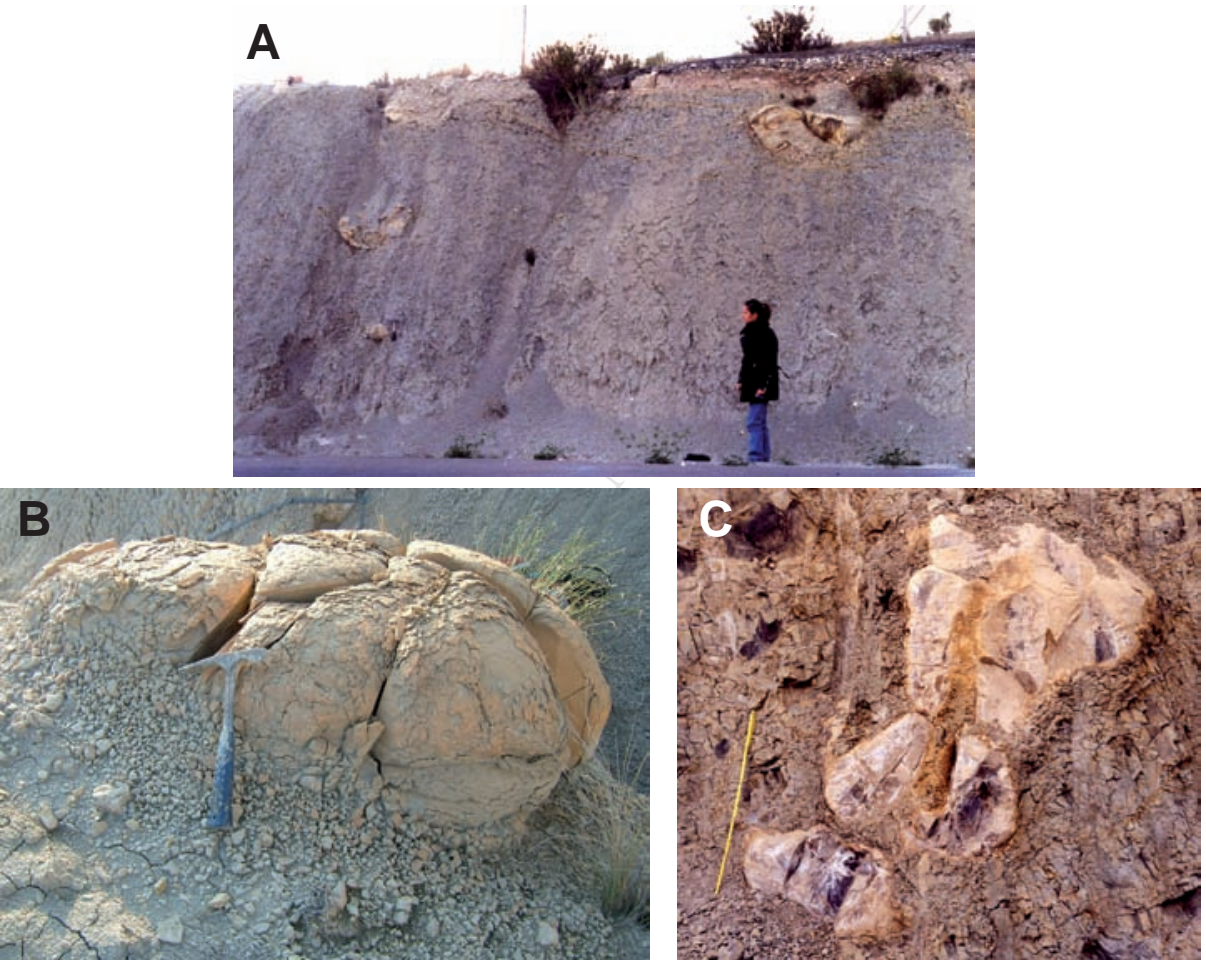


\begin{tabular}{|c|c|}
\hline Quartz & @ Calcite \\
\hline ther silicates & \\
\hline
\end{tabular}

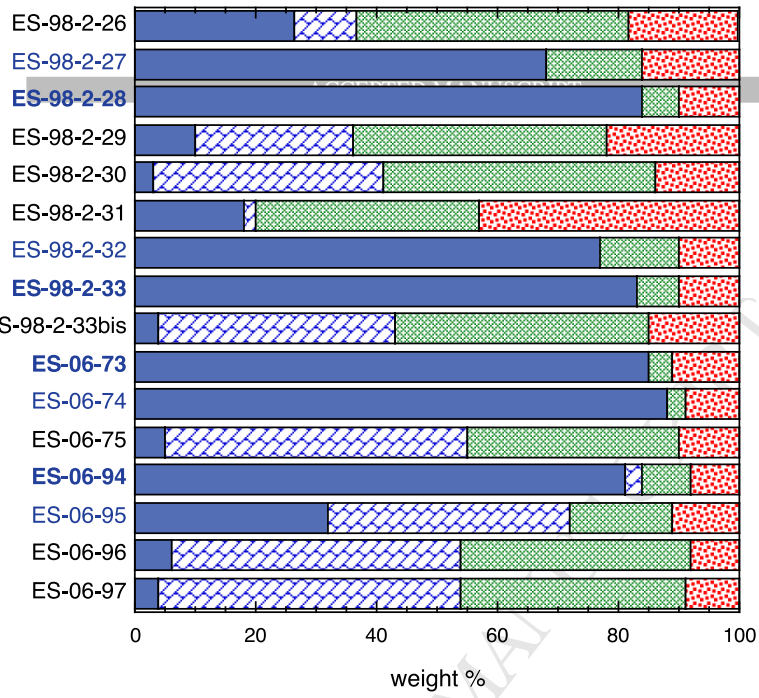

B

图 Chlorite $\square$ Smectite @ Illite

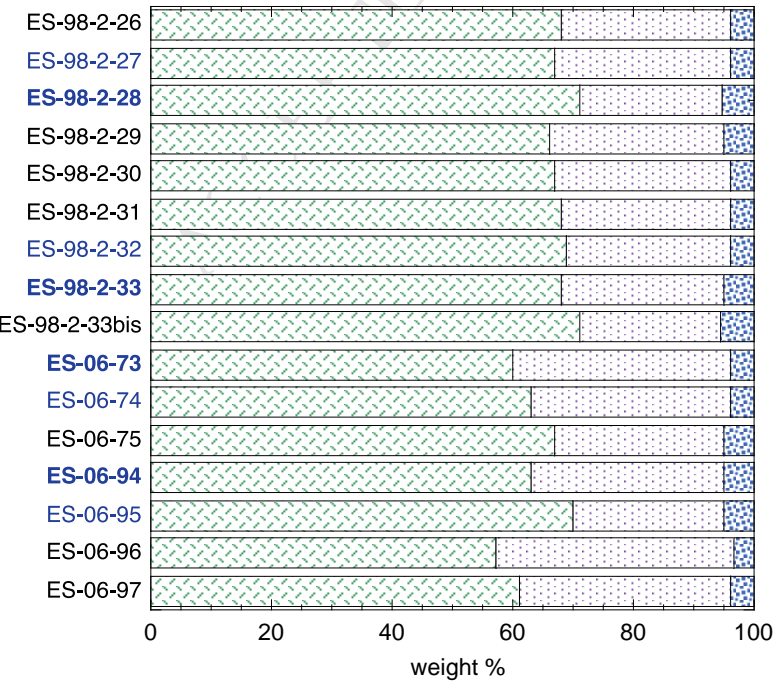



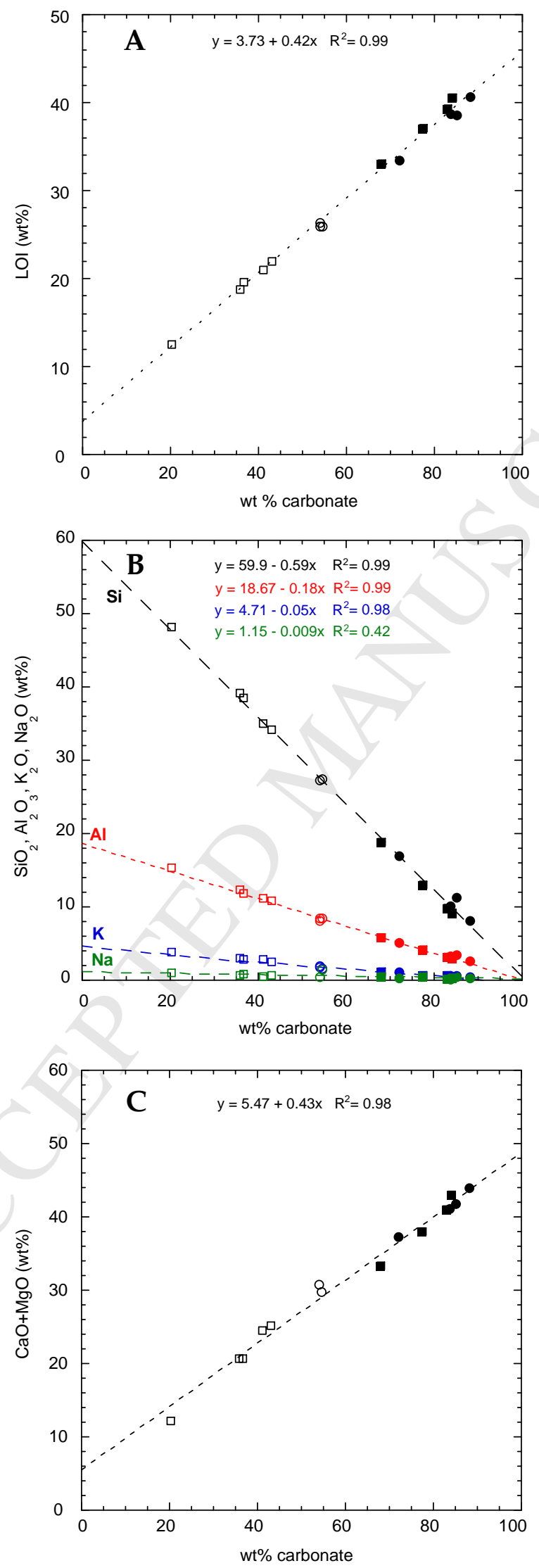


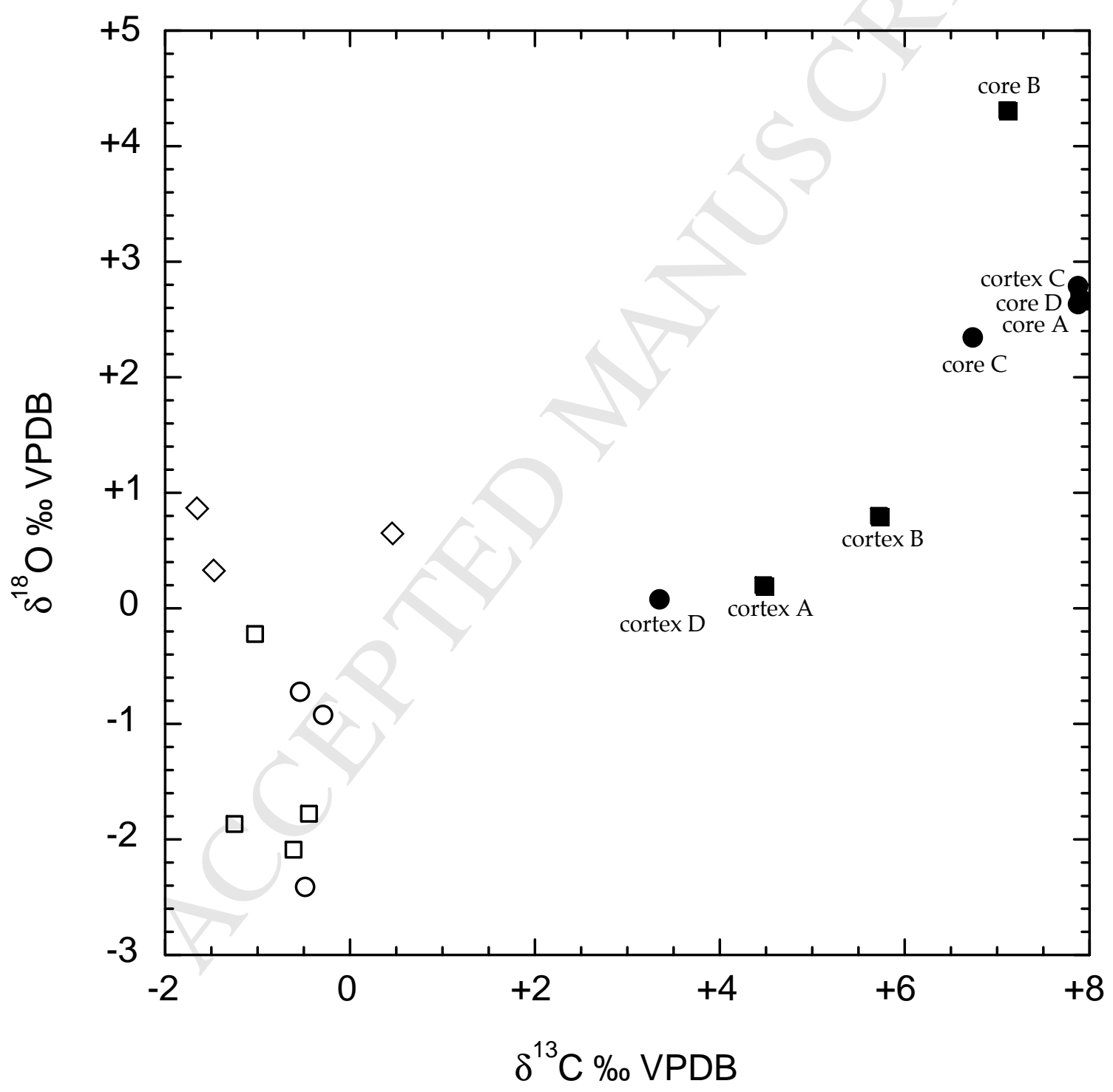

